\title{
Article \\ Characterisation of Industrial Side Streams and Their Application for the Production of Geopolymer Composites
}

\author{
Mehmet Emin Küçük ${ }^{1, *}$, Teemu Kinnarinen ${ }^{1}$, Juha Timonen ${ }^{2}$, Olli Mulari ${ }^{2}$ and Antti Häkkinen ${ }^{1}$ D \\ 1 LUT School of Engineering Science, Lappeenranta-Lahti University of Technology, Yliopistonkatu 34, \\ 53850 Lappeenranta, Finland; teemu.kinnarinen@lut.fi (T.K.); Antti.Hakkinen@lut.fi (A.H.) \\ 2 Apila Group Ltd., Hietalantie 7A, 80710 Lehmo, Finland; juha.timonen@apilagroup.fi (J.T.); \\ olli.mulari@apilagroup.fi (O.M.) \\ * Correspondence: mehmet.kucuk@lut.fi
}

check for

updates

Citation: Küçük, M.E.; Kinnarinen, T.; Timonen, J.; Mulari, O.; Häkkinen, A. Characterisation of Industrial Side Streams and Their Application for the Production of Geopolymer Composites. Minerals 2021, 11, 593. https: / / doi.org/10.3390/ $\min 11060593$

Academic Editor: Thomas

N. Kerestedjian

Received: 8 May 2021

Accepted: 27 May 2021

Published: 31 May 2021

Publisher's Note: MDPI stays neutral with regard to jurisdictional claims in published maps and institutional affiliations.

Copyright: (c) 2021 by the authors. Licensee MDPI, Basel, Switzerland. This article is an open access article distributed under the terms and conditions of the Creative Commons Attribution (CC BY) license (https:/ / creativecommons.org/licenses/by/ $4.0 /)$.

\begin{abstract}
This study focuses on characterisation of side streams including biomass fly ash, biomass bottom ash, coal fly ash, green liquor dregs, limestone mine tailings, and electric arc furnace steel slag from different industrial locations in Finland. It was found that the fly ash samples contained the highest $\mathrm{Al}_{2} \mathrm{O}_{3}$ and $\mathrm{SiO}_{2}$ concentrations, a large number of spherical particles of small sizes and high specific surface areas. Fly ashes and steel slag were observed to contain higher amounts of amorphous phases compared to the other side streams. The high loss on ignition value of the coal fly ash and green liquor dregs was found to exceed the limitations for their application in geopolymer composites. Despite their relatively high concentrations in ashes and steel slag, the leaching tests have shown that no hazardous metal leached out from the streams. Finally, test specimens of geopolymer composites (GP2) were prepared by the application of biomass fly ash, bottom ash, and limestone mine tailings without any pre-treatment process, in addition to the ordinary Portland cement-(R) and metakaolin-based geopolymer composites (GP1). The measured compressive (14.1 MPa) and flexural strength $(3.5 \mathrm{MPa}$ ) of GP2 suggest that it could be used in concrete kerbs and paving flags. The data has also shown that over $500 \%$ of the compressive strength was developed between 7 and 28 days in GP2, whereas in the case of reference concrete (R) and the metakaolin-based geopolymer composite (GP1) it was developed in the first 7 days.
\end{abstract}

Keywords: biomass fly ash; biomass bottom ash; limestone mine tailings; characterisation; geopolymer composite

\section{Introduction}

According to the 2030 climate and energy framework adopted by the European Council in October 2014, the target for 2030 is to reduce the GHG (greenhouse gas) emissions by $40 \%$ (from 1990 levels), to increase the share of renewable energy to at least 32\%, and to improve the energy efficiency to $32.5 \%$ [1]. Therefore, continuous efforts are required; for instance, the cement industry, on a global scale, is responsible for $8 \%$ of world's $\mathrm{CO}_{2}$ emissions despite improvements in terms of energy efficiency [2]. As part of the attempts to address issues related to waste management and greenhouse gas emissions in the construction industry, numerous studies have been conducted that consider the use of geopolymer composites as an alternative to ordinary Portland cement (OPC) [3-5].

Geopolymer composites are inorganic materials that have been produced by polymerisation of materials with high aluminosilicate contents. The polymerisation is a result of the fast chemical reaction of silica and aluminosilicate under strong alkaline conditions with, e.g., $\mathrm{NaOH}, \mathrm{Ca}(\mathrm{OH})_{2}, \mathrm{Na}_{2} \mathrm{O}, \mathrm{LiOH}$, and $\mathrm{Na}_{2} \mathrm{SiO}_{3}$ [6]. Different polymeric chains may be generated, such as poly(sialate)(-Si-O-Al-O-)n, poly(sialate-siloxo) (-Si-O-Al-O-Si-O-)n, poly(sialate-disiloxo)(-Si-O-Al-O-Si-O-Si-O-)n, and poly(sialate-multisiloxo), depending on the reaction conditions [7]. 
Geopolymer composites can be used in the construction industry as alternatives to ordinary concrete as they can possess good mechanical, thermal, and chemical properties [7-9]. The characteristics of the produced geopolymer composite are highly dependent on a great number of variables, including the alkali chemicals used [6], the concentration of the alkali in solutions $[9,10]$, the aluminosilicate sources $[3,10]$ the solid/liquid ratio [10], the ratios of $\mathrm{Si} / \mathrm{Al}, \mathrm{Na} / \mathrm{Al}$ and $\mathrm{Ca} / \mathrm{Al}$ [11], the addition of fibres or aggregates [5], particle size distribution of the solids [8,12], curing time [10] and temperature [11].

Fillers (aggregates) are inorganic or organic materials incorporated in a cementitious product to enhance its durability, mechanical properties and microstructural characteristics through increasing its packing density $[5,13]$. Packing density of an aggregate is defined as the ratio between the solid volume of the aggregate and its bulk volume, and it determines the filling degree of the voids in the concrete by the aggregate solids. The voids between the aggregates must be prevented as high voids ratio which is responsible for poor workability and increased water demand [13,14]. According to ISO 19595:2017 (Natural aggregates for concrete), the maximum particle size for fine aggregates is $4 \mathrm{~mm}$. Materials with higher particle sizes could be used as coarse aggregates.

Approximately 780 million tonnes of coal ash are produced annually [15], and the production rate of the biomass ash is 476 million tonnes per year [16]. Depending on (1) biomass characteristics, (2) combustion technology and (3) the location of the ashes collected, the properties of biomass ashes vary [3]. Due to their abundance, fine particle size distribution, and high vitreous contents which contain the soluble aluminosilicate species [4], fly ashes are some of the most frequently used sources of aluminosilicates for geopolymer composites [3,17-19].

In the pulp and paper industry, the major solid residue is in the form of green liquor dregs (GLD) generated during the chemical recovery cycle following Kraft pulp production. Even though the exact worldwide production of GLD is unknown, a recent study estimated that 0.5 to 1.3 million tonnes of GLD is produced annually [20]. The main constituents of GLD are metal oxides, carbonates of sodium, magnesium and calcium, and organic matter [5,21]. Due to their low content of $\mathrm{Al}_{2} \mathrm{O}_{3}$ and $\mathrm{SiO}_{2}$, dregs cannot be considered suitable as binders $[5,22]$. Nevertheless, they have been successfully applied as fine fillers in geopolymer composites [5].

Mine tailings (MT) are residual wastes in slurry generated during production of metals, minerals or coal. The mining industry is one of the world's largest producers of waste with approximately 14 billion tonnes of tailings produced annually [23]. In addition to the high costs of tailings storage and dam maintenance, tailings pose significant environmental risks such as acidic mine drainage and tailings dam failures. Reduction of these risks is possible through sustainable management and effective recycling of tailings. MT have found applications in geopolymer composites in corporation with glass wool residue [9], and in road construction material in the form of geopolymer composites [24].

In 2012, roughly 21.4 million tonnes of steel slag were produced in Europe, of which 8.1 million tonnes were electric arc furnace (EAF) slag [25]. The major constituents of EAF steel slags are $\mathrm{SiO}_{2}, \mathrm{Al}_{2} \mathrm{O}_{3}, \mathrm{Fe}_{2} \mathrm{O}_{3}$ and $\mathrm{CaO}$ [26]. The application of EAF steel slag in construction materials is hampered by swelling of the material due to the hydroxylation and carbonation of free lime with moisture. Prevention of these reactions is possible through curing and weathering of the slag by producing a $\mathrm{CaCO}_{3}$ layer on the surface of the material [27]. The high iron content is responsible for the rough surface of the material and it decreases the workability of the concrete mixture [28]. However, its incorporation in geopolymer composites with fly ash [29], and with cement kiln dust [26] have been studied so far.

It is reasonable to find interconnections between the physical and chemical characteristics of the side streams and possibility of their potential use as aluminosilicate sources and as fillers (aggregates) in geopolymer composites. This paper focuses on characterisation of several important industrial side streams, namely, biomass fly ash, coal fly ash, biomass bottom ash, green liquor dregs, limestone mine tailings and electric arc furnace 
steel slag from different industrial locations in Finland. To demonstrate the findings in practice, a geopolymer composite was produced using different residues without any pre-treatment, and preliminary results on the strength of the material were compared with those of OPC concrete. For this purpose, a number of analytical methods (PSD, BET, Digital image analysis, SEM, EDS, XRF, XRD, ICP and TGA) were used to investigate the composition and structure of the side streams in addition to the leaching study to evaluate their chemical stability in aqueous environment. Finally, the compressive and flexural strength tests were performed to determine the mechanical properties of the produced geopolymer composites.

\section{Materials and Methods}

\subsection{Origins of the Samples}

The total amount of samples considered in this study was eight, and they were all collected from industrial plants in Finland. The origins of the samples and the notations used are presented in Table 1.

Table 1. Origins of the side streams.

\begin{tabular}{|c|c|c|c|}
\hline Sample & Notation & Origin & Details \\
\hline Fly ash 1 & FA1 & Bark boiler in pulp mill & $\begin{array}{c}\text { Fuels: bark, wood residues, paper } \\
\text { mill reject sludges }\end{array}$ \\
\hline Fly ash 2 & FA2 & Co-incineration plant of a pulp mill & $\begin{array}{l}\text { Fuels: bark, wood chips, recycled } \\
\text { wood, natural gas, wastewater sludge }\end{array}$ \\
\hline Fly ash 3 & FA3 & Coal power plant & Fuels: coal, wood pellets \\
\hline Bottom ash & BA & Co-incineration plant of a pulp mill & $\begin{array}{l}\text { Fuels: bark, wood chips, recycled } \\
\text { wood, natural gas, wastewater sludge }\end{array}$ \\
\hline Green liquor dregs & GLD & Kraft pulp mill & Separated from green liquor \\
\hline Limestone mine tailings (fine) & MTF & Limestone mine & Settling in limestone tailings pond \\
\hline Limestone mine tailings (coarse) & MT & Limestone mine & Settling in limestone tailings pond \\
\hline Steel slag & SS & Electric arc furnace & Natural cooling, crushing \\
\hline
\end{tabular}

\subsection{Analyses}

Particle size distributions (PSD) of the samples were measured with a laser diffraction particle size analyser with a Hydro EV particle dispersing unit (Malvern Mastersizer 3000, Malvern Instruments, Malvern, UK). The PSD of bottom ash (BA) was not measured as the particle size of the sample exceeded the operating range of the equipment $(3 \mathrm{~mm})$. Image analyses were performed with Morphologi G3 particle characterisation equipment (Malvern Instruments, UK). The original steel slag consisted of large aggregates; therefore, it was necessary to homogenise it for the study. Due to the major change in the structure of the steel slag following crushing, PSD measurements and image analysis were not performed for this sample. The specific surface areas (SSA) were measured with a BET surface area analyser (Micromeritics 3Flex, Norcross, GA, USA) under nitrogen atmosphere. The SSA of the steel slag sample was not measured for the above-mentioned reason. A scanning electron microscope (SEM) was used to investigate the surface topography of the samples; elemental compositions were obtained by energy-dispersive $\mathrm{X}$-ray spectroscopy (EDS) mapping (Hitachi SU 3500 scanning electron microscope, Tokyo, Japan). The BA and MT samples were manually crushed for SEM and EDS analyses. EDS analysis was performed for at least 3 points for each sample and the average value was taken. Elemental compositions were obtained by a sequential X-ray fluorescence spectrometer (XRF) (Bruker AXS S4 Pioneer, Billerica, MA, USA). Carbon and sulphur contents were determined by a LECO CS844 Analyser (LECO, St. Joseph, MI, USA). Bottom ash (BA) and FA2 (biomass fly ash 2) were ground prior to the XRF and carbon and sulphur analyses. All samples underwent X-ray diffraction (XRD) analysis to investigate their mineral compositions. The samples were homogenised with a pestle and mortar prior to the analyses. The mineral compositions were determined with an X-ray diffractometer (Bruker D8 Advance X-ray 
diffractometer, Billerica, MA, USA, Cu source-K $\alpha=1.5406 \AA$ ). Metal concentrations were determined by inductively coupled plasma mass spectroscopy (ICP-MS). ICP-MS analyses were performed after complete digestion using standardized 4-acid digestion and peroxide smelt digestion methods. The leaching tests were performed according to EN-12457-2 (shaking for $24 \mathrm{~h}, \mathrm{~L} / \mathrm{S}=10$ ), which was followed by filtration of the leachates and their analysis by ICP-MS (Agilent 799 inductively coupled plasma mass spectrometer, Santa Clara, CA, USA). The thermogravimetric analyses (TGA) were performed with a thermomicrobalance (Netzsch STA 449 C Jupiter, Netzsch-Gerätebau, Selb, Germany). The original solid samples were heated from 25 to $1200^{\circ} \mathrm{C}$ at a constant heating rate of $10^{\circ} \mathrm{C} / \mathrm{min}$ under air atmosphere. An online mass spectrometer was used for identification of the gaseous products (QMS Netzsch, Selb, Germany).

\subsection{Preparation and Testing of the Geopolymer Composites}

Two different geopolymer composites were prepared: 1) Metakaolin-based geopolymer composite (GP1) (Argical M1000, Imerys S.A.) and 2) Biomass fly ash-based geopolymer composite (GP2) by Apila Group Ltd. In addition, an OPC (Plussementti CEM II/B-M (S-LL), Finnsementti Oy) concrete was prepared and used as a reference material. A commercial coal fly ash (Ecofax M20, Fatec Oy) was incorporated as the binder material in addition to FA1 in GP2. The mixture design of the geopolymer composites is presented in Table 2.

Table 2. Mixture design used in the preparation of the composites; values expressed in wt.\%.

\begin{tabular}{ccccccccc}
\hline Mix No. & FA1 & BA & MTF & MT & OPC & Metakaolin & Coal Fly Ash (Ecofax) \\
\hline R & - & 20.7 & 8.9 & 30.9 & 27.3 & - & - \\
GP1 & - & 17.5 & 13.1 & 26.2 & - & 13.2 & 19.2 \\
GP2 & 16.6 & - & - & 30.0 & - & - & 36.9 \\
\hline
\end{tabular}

The preparation of the materials was performed as follows. A premixed $\mathrm{Na}_{2} \mathrm{SiO}_{3} / \mathrm{NaOH} / \mathrm{H}_{2} \mathrm{O}$ solution with a solids content of $44 \%$ and $\mathrm{SiO}_{2} / \mathrm{Na}_{2} \mathrm{O}$ weight ratio of 1.7 (Geosil 34417, Woellner $\mathrm{GmbH}$, Ludwigshafen, Germany) was cooled to room temperature and poured into a 20-L capacity Hobart-mixer followed by the addition of the aluminosilicate precursors and aggregates. The mixture was blended for $3 \mathrm{~min}$ at low speed (107 rpm), and the fresh pastes were then placed inside the moulds of sizes $100 \times 100 \times 100 \mathrm{~mm}^{3}$ for the compressive strength tests, and of $40 \times 40 \times 160 \mathrm{~mm}^{3}$ for the flexural strength tests. The moulds were vibrated for $15-45 \mathrm{~s}$ to level the cast surface and to release the air bubbles inside. A plastic sheet was utilised to cover the samples to prevent the moisture loss. The samples were cured while wrapped in an air-tight plastic at room temperature $\left(20 \pm 1^{\circ} \mathrm{C}\right)$ for 7 and 28 days for mechanical testing. Sample cubes and prisms were tested according to standards SFS-EN 12390-3 (compressive strength, ELE International, ADR-Auto, 2000kN), SFS-EN 12390-5:2019 (flexural strength, Instron 5581) and SFS-EN 1340 attachment G (Wide wheel abrasion, S.A.E Ibertest DIB-70).

\section{Results and Discussion}

\subsection{Particle Size Distributions and Specific Surface Areas}

Particle size distributions and specific surface areas of the samples are shown in Table 3 and Figure 1. MTF contains the finest particles with FA3, while MT were found to consist of coarser particles leading to a smaller specific surface area. Interestingly, FA2 has a smaller surface area than FA1 considering its fine particle size distribution. Similarly, the specific surface area of MTF was found to be very small despite its fine particle size distribution. A possible explanation for this might be the smaller amount of carbon present in this sample compared to the others, as the correlation between the specific surface area and unburnt carbon content is widely acknowledged [30]. It seems also possible that, FA1 might contain higher number of porous, or generally more porous, particles compared to FA2, resulting a higher specific surface area than FA2. 
Table 3. Particle size distribution values (D10, D50, D90) and BET specific surface areas of the side streams.

\begin{tabular}{ccccc}
\hline Side Stream & D10 $(\mu \mathrm{m})$ & D50 $(\mu \mathrm{m})$ & D90 $(\mu \mathrm{m})$ & BET $\left(\mathbf{m}^{2} / \mathbf{g}\right)$ \\
\hline FA1 & 11.3 & 54.5 & 184 & 9.27 \\
FA2 & 7.32 & 30.7 & 116 & 1.73 \\
FA3 & 3.67 & 26.5 & 108 & 13.7 \\
BA & - & - & - & 0.07 \\
GLD & 7.29 & 34.7 & 103 & 8.08 \\
MTF & 1.69 & 11.9 & 84.9 & 1.07 \\
MT & 34.7 & 147 & 311 & 0.33 \\
\hline
\end{tabular}

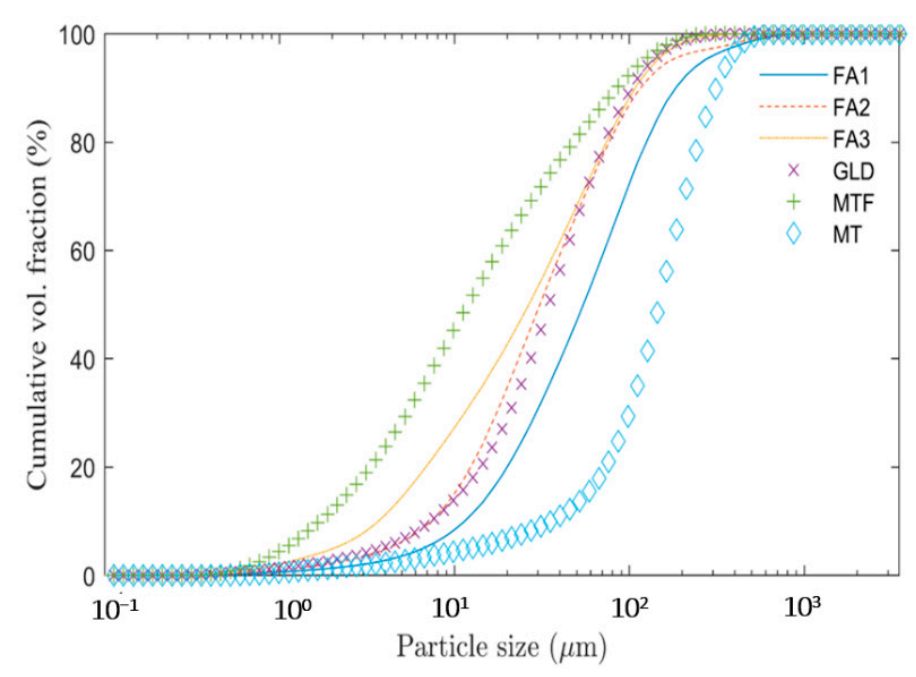

Figure 1. Cumulative particle size distributions of the samples.

In geopolymeric reactions, the reactivity of the raw materials usually increases with particle fineness due to the increased surface area, which subsequently improves the mechanical properties of the geopolymer composite [4]. This improvement could also be attributed to the increased $\mathrm{SiO}_{2} / \mathrm{Al}_{2} \mathrm{O}_{3}$ ratio, which is known to provide the optimal binding properties to the geopolymer composite when it is within the range of 2.0 to 3.5; and reduced contents of hematite $\left(\mathrm{Fe}_{2} \mathrm{O}_{3}\right)$, lime $(\mathrm{CaO})$ and loss on ignition [12,31]. In addition, finer particles are known to improve the microstructure of the final composite by decreasing the capillary pore size in the structure [8]. When the four different types of ashes investigated in this study are assessed from this point of view, FA1, FA2 and FA3 could potentially produce geopolymer composites with better microstructural characteristics and mechanical properties, compared to the ones produced from BA. The elimination of coarse particles in BA must be performed by milling. From the aggregates point of view, MTF and GLD seem to be promising fine aggregates as they do not contain particles larger than $4 \mathrm{~mm}$. Li et al. (2017) observed that the durability and compressive strength of the concrete increased with the addition of fine limestone fillers (D50 = $13.6 \mu \mathrm{m})$, and concluded that different fillers with similar particle sizes would have the same effect on concrete through increased packing density [13]. BA and MT, on the other hand, could be used as a coarse aggregate due to their coarse particle size distribution.

\subsection{Digital Image Analysis}

Aspect ratio, circularity (roundness), and convexity values of the samples are presented in Table 4 . The aspect ratio is defined as $D_{\max } / D_{\min }$, where $D_{\max }$ and $D_{\min }$ are the largest and smallest dimensions of the projected particle [32]. Circularity indicates the similarity degree of the particle to a circle, and it is given with the equation $4 \pi S / P^{2}$ where $S$ is the area and $P$ is the perimeter [32]. Convexity is the ratio of the hull perimeter to the perimeter, and it is a measure of the overall roundness of a particle [32]. 
Table 4. Circularity, convexity and aspect ratio of each sample.

\begin{tabular}{ccccc}
\hline Sample & $\begin{array}{c}\text { Number of } \\
\text { Measured Particles }\end{array}$ & Circularity (-) & Convexity (-) & Aspect Ratio (-) \\
\hline FA1 & 203,706 & 0.951 & 0.997 & 1.208 \\
FA2 & 344,141 & 0.939 & 0.996 & 1.269 \\
FA3 & 263,401 & 0.948 & 0.996 & 1.203 \\
BA & 4,579 & 0.859 & 0.991 & 1.543 \\
GLD & 254,458 & 0.939 & 0.997 & 1.274 \\
MTF & 154,679 & 0.932 & 0.993 & 1.429 \\
MT & 42,108 & 0.902 & 0.995 & 1.410 \\
\hline
\end{tabular}

In a study investigating the influence of aspect ratio, convexity and circularity, it was reported that increasing the aspect ratio has a major negative influence on the packing density of sand grains, while the strongly correlated parameters convexity and circularity have a minor positive effect on the packing performance of the same materials [32]. In a comprehensive study investigating the impact of particle circularity on the packing density of natural and crushed sands, it was found that with more circular particles, it is possible to reduce the void ratio, and thereby to produce a matrix with high packing density [33]. The convexity was reported to be proportional to the packing density [14], and it was attributed to the difficulty of filling the voids between concave particles [34]. The highest circularity values obtained for fly ashes are consistent with the SEM analysis results presented in Section 3.3, where also high contents of cenospheres can be observed. In this study, the side streams investigated with respect to their potential utilisation as aggregates are limestone tailings, green liquor dregs and bottom ash. According to Table 4, the convexities of the side streams do not vary significantly. However, the lowest circularity (0.859) and highest aspect ratio (1.543) measured for the bottom indicate that it would impair the packing density and mechanical characteristics of the final material in case of its application without milling.

\subsection{Surface Morphologies and Chemical Compositions}

Sample morphologies determined with SEM are shown in Figure 2. The relative $\mathrm{Al}$ and $\mathrm{Si}$ concentrations of the samples are presented in the mappings (Figure S1). Figure 2A-C present biomass fly ash and coal fly ash samples. These samples consist of irregularlyshaped, hollow and spherical particles (cenospheres), which have been observed in other studies [5,35]. The dark and irregularly shaped particles seen in coal fly ash, for instance in the centre of Figure 2C, are likely related to unburnt carbon, which is an inference supported by the high carbon concentrations obtained by the EDS analysis (Table 5). Figure 2 shows that fly ashes (Figure 2A-C), GLD (Figure 2E) and MTF (Figure 2F) consist of particles with smaller sizes compared to the other samples. On the other hand, BA (Figure 2D) and MT (Figure 2G) contain large, square and irregularly-shaped particles. Of the two different zones of the SS (Figure 2H), the lighter zone is considered to contain high concentrations of iron, while calcium is thought to be present at high concentrations in the darker zone [27].

The chemical compositions of the industrial side streams determined with EDS and XRF are presented in Tables 5 and 6, respectively. It is apparent from these tables that GLD contain a very small amount of $\mathrm{SiO}_{2}$ and $\mathrm{Al}_{2} \mathrm{O}_{3}$ and MT have a very low $\mathrm{Al}_{2} \mathrm{O}_{3}$ content resulting in a $\mathrm{SiO}_{2} / \mathrm{Al}_{2} \mathrm{O}_{3}$ ratio of 26.3. The $\mathrm{SiO}_{2}$ content is very high in the case of $\mathrm{BA}$; however, its coarse particle size distribution and low specific surface area would hinder its dissolution during the geopolymerisation. Even though the $\mathrm{SiO}_{2} / \mathrm{Al}_{2} \mathrm{O}_{3}$ ratios are similar among the other samples, the highest concentrations of these components can be found in coal fly ash (FA3). Similar results have been previously reported for coal fly ash [17], biomass fly ash [36] and electric arc furnace steel slag [28]. 

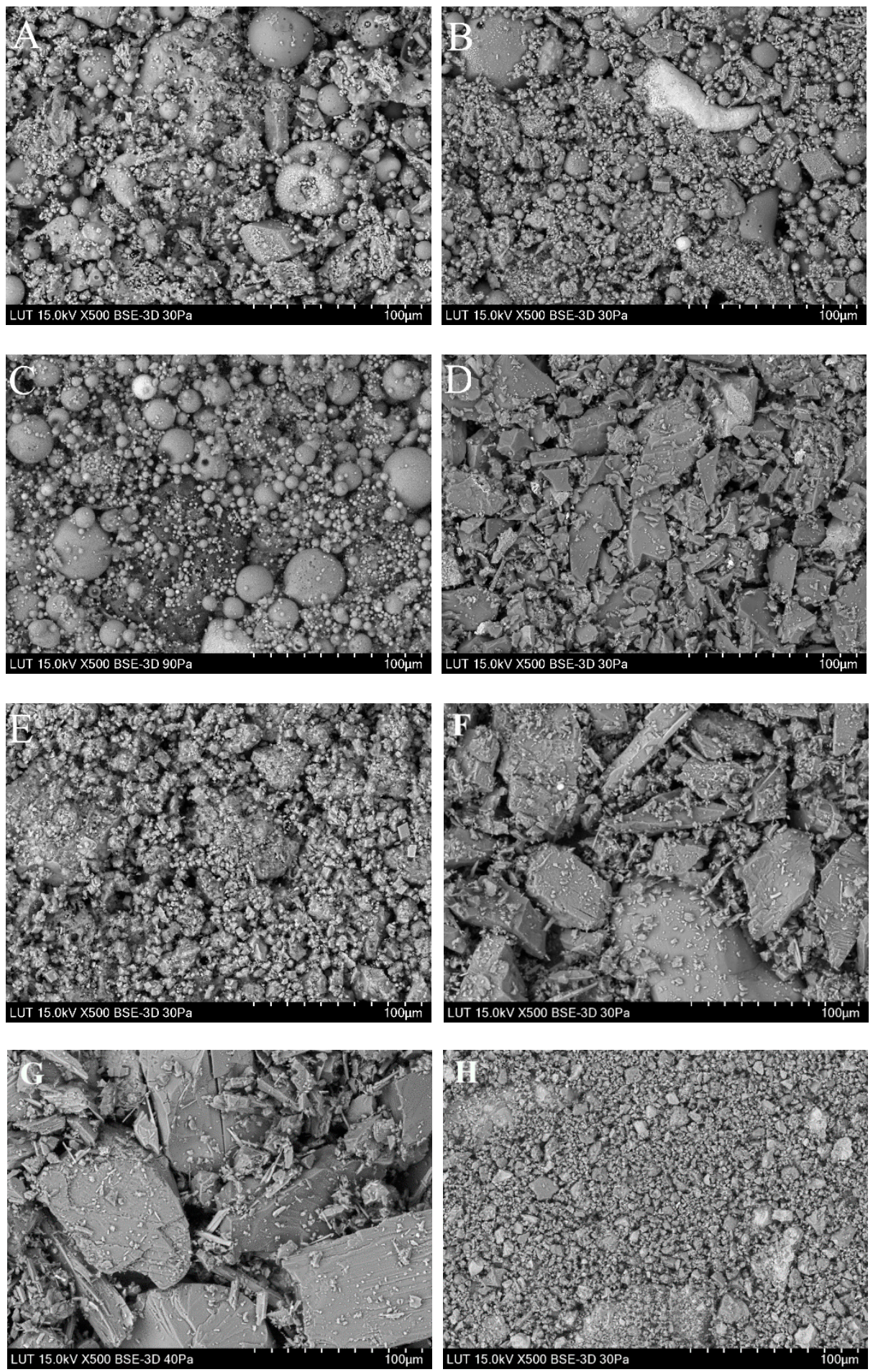

Figure 2. SEM micrographs of the samples, (A): biomass fly ash 1 (FA1), (B): biomass fly ash 2 (FA2), (C): Coal fly ash (FA3), (D): bottom ash (BA), (E): green liquor dregs (GLD), (F): fine limestone tailings (MTF), (G): coarse limestone tailings (MT), (H): electric arc furnace steel slag (SS). 
Table 5. Chemical compositions of the samples obtained with EDS analysis; values expressed in wt.\%.

\begin{tabular}{|c|c|c|c|c|c|c|c|c|}
\hline Element & FA1 & FA2 & FA3 & BA & GLD & MTF & MT & SS \\
\hline & wt. $\%$ & wt.\% & wt.\% & wt.\% & wt. $\%$ & wt.\% & wt.\% & wt.\% \\
\hline $\mathrm{C}$ & $6.5 \pm 0.3$ & $4.3 \pm 0.2$ & $35 \pm 0.2$ & $2.3 \pm 0.3$ & $9.5 \pm 0.1$ & $11 \pm 0.1$ & $7.7 \pm 0.1$ & $4.4 \pm 0.1$ \\
\hline $\mathrm{O}$ & $36 \pm 0.2$ & $35 \pm 0.3$ & $36 \pm 0.2$ & $47 \pm 0.2$ & $47 \pm 0.4$ & $44 \pm 0.2$ & $44 \pm 0.2$ & $24 \pm 0.1$ \\
\hline $\mathrm{Na}$ & $1.8 \pm 0.1$ & $3.6 \pm 0.1$ & 0.5 & $2.5 \pm 0.1$ & $9.8 \pm 0.1$ & $0.5 \pm 0.1$ & $0.5 \pm 0.1$ & - \\
\hline $\mathrm{Mg}$ & $1.1 \pm 0.1$ & $1.3 \pm 0.1$ & 0.4 & 0.2 & $4.8 \pm 0.2$ & $1.3 \pm 0.2$ & $2.6 \pm 0.1$ & $1.2 \pm 0.1$ \\
\hline $\mathrm{Al}$ & $6.5 \pm 0.1$ & $3.3 \pm 0.2$ & $7.1 \pm 0.1$ & $5.6 \pm 0.2$ & 0.3 & $1.1 \pm 0.2$ & $1.2 \pm 0.1$ & $3.1 \pm 0.1$ \\
\hline $\mathrm{Si}$ & $6.1 \pm 0.1$ & $6.0 \pm 0.4$ & $15 \pm 0.1$ & $30 \pm 0.4$ & $1 \pm 0.1$ & $10 \pm 0.3$ & $16 \pm 0.4$ & $6.1 \pm 0.1$ \\
\hline $\mathrm{P}$ & $1.1 \pm 0.1$ & $0.7 \pm 0.1$ & 0.2 & - & 0.1 & - & - & - \\
\hline$S$ & $2.9 \pm 0.1$ & $6.6 \pm 0.1$ & - & - & $2.2 \pm 0.1$ & - & - & 0.2 \\
\hline $\mathrm{Cl}$ & $1 \pm 0.1$ & $3.4 \pm 0.1$ & - & 0.2 & - & - & - & - \\
\hline $\mathrm{K}$ & $3.5 \pm 0.2$ & $3.2 \pm 0.1$ & $1.3 \pm 0.1$ & $3.2 \pm 0.1$ & 0.2 & $0.4 \pm 0.1$ & $0.4 \pm 0.1$ & - \\
\hline $\mathrm{Ca}$ & $31 \pm 0.1$ & $27 \pm 0.6$ & $1.7 \pm 0.1$ & $6.9 \pm 0.2$ & $23 \pm 0.1$ & $32 \pm 0.2$ & $27 \pm 0.2$ & $34 \pm 0.2$ \\
\hline $\mathrm{Ti}$ & 0.2 & $1.4 \pm 0.1$ & $0.5 \pm 0.1$ & $0.6 \pm 0.1$ & - & - & - & 0.4 \\
\hline $\mathrm{Mn}$ & $1.3 \pm 0.1$ & $0.6 \pm 0.1$ & - & - & $2.3 \pm 0.1$ & - & - & $3.9 \pm 0.1$ \\
\hline $\mathrm{Fe}$ & $0.7 \pm 0.1$ & $2.1 \pm 0.2$ & $2.4 \pm 0.1$ & $2 \pm 0.2$ & $0.5 \pm 0.1$ & $0.7 \pm 0.1$ & $0.9 \pm 0.1$ & $21 \pm 0.2$ \\
\hline $\mathrm{Zn}$ & - & $1.2 \pm 0.1$ & - & - & - & - & - & - \\
\hline $\mathrm{Cr}$ & - & - & - & - & - & - & - & $1.6 \pm 0.1$ \\
\hline
\end{tabular}

Table 6. Chemical compositions of the samples obtained with XRF analysis; values expressed in wt.\%.

\begin{tabular}{|c|c|c|c|c|c|c|c|}
\hline Component & FA1 & FA2 & FA3 & BA & GLD & MT & SS \\
\hline & wt. $\%$ & wt. $\%$ & wt. $\%$ & wt. $\%$ & wt. $\%$ & wt. $\%$ & wt. $\%$ \\
\hline $\mathrm{SiO}_{2}$ & 24.4 & 27.7 & 54.6 & 68.2 & 2.3 & 48.1 & 27.7 \\
\hline $\mathrm{Al}_{2} \mathrm{O}_{3}$ & 17.7 & 11.1 & 20.6 & 11.0 & 0.6 & 3.1 & 5.1 \\
\hline $\mathrm{CaO}$ & 34.7 & 31.5 & 3.4 & 6.8 & 32.6 & 30.5 & 36.1 \\
\hline $\mathrm{Fe}_{2} \mathrm{O}_{3}$ & 1.7 & 4.5 & 5.0 & 3.2 & 0.5 & 1.3 & 32.1 \\
\hline $\mathrm{MgO}$ & 2.9 & 3.4 & 1.9 & 0.8 & 8.0 & 8.2 & 3.8 \\
\hline $\mathrm{Na}_{2} \mathrm{O}$ & 2.0 & 2.8 & 0.9 & 2.8 & 9.5 & 0.7 & 0.2 \\
\hline $\mathrm{K}_{2} \mathrm{O}$ & 3.0 & 2.7 & 2.2 & 3.3 & 0.2 & 0.5 & 0.03 \\
\hline $\mathrm{Mn}_{3} \mathrm{O}_{4}$ & 1.1 & 0.7 & 0.05 & 0.2 & 2.2 & 0.03 & 6.0 \\
\hline $\mathrm{Cr}_{2} \mathrm{O}_{3}$ & 0.03 & 0.09 & 0.01 & 0.08 & 0.03 & $<0.01$ & 2.2 \\
\hline $\mathrm{P}_{2} \mathrm{O}_{5}$ & 2.3 & 1.6 & 0.7 & 0.3 & 0.4 & 0.2 & 0.5 \\
\hline $\mathrm{SO}_{3}$ & 4.3 & 6.3 & 0.1 & 0.2 & 3.2 & 0.1 & 0.3 \\
\hline $\mathrm{TiO}_{2}$ & 0.3 & 0.3 & 0.8 & 0.6 & 0.01 & 0.1 & 0.4 \\
\hline $\mathrm{LOI}_{950^{\circ} \mathrm{C}}$ & 5 & 4.8 & 9.3 & 1.1 & 39.9 & 7.1 & 0.4 \\
\hline $\begin{array}{c}\mathrm{SiO}_{2} / \mathrm{Al}_{2} \mathrm{O}_{3} \\
\text { wt. } \%\end{array}$ & 1.38 & 2.50 & 2.65 & 6.20 & 3.83 & 15.5 & 2.41 \\
\hline $\mathrm{SiO}_{2} / \mathrm{Al}_{2} \mathrm{O}_{3}$ & 2.34 & 4.23 & 4.50 & 10.5 & 6.50 & 26.3 & 9.21 \\
\hline$C$ & 1.14 & 0.75 & 8.2 & 0.09 & 8.9 & 1.8 & 0.56 \\
\hline$S$ & 1.92 & 3.2 & 0.09 & 0.09 & 1.7 & 0.09 & 0.11 \\
\hline
\end{tabular}

$\mathrm{CaO}$ improves the pozzolanic properties of aluminosilicate precursors by its conversion to $\mathrm{Ca}(\mathrm{OH})_{2}$ in the presence of water. $\mathrm{Ca}(\mathrm{OH})_{2}$ forms C-S-H (calcium silicate hydrate) when reacted with $\mathrm{Si}$, which is known to enhance the compressive strength of the composite material in addition to the geopolymeric gel [37]. However, excessive amounts of $\mathrm{CaO}$ reduces the setting time of the composite significantly, which results in poor workability properties to the composite. Furthermore, it may interfere the geopolymerisation reaction between sodium and the aluminosilicates. As a result of the incomplete reaction, the compressive strength of the material decreases significantly.

The influence of excess iron oxide is similar to that of calcium oxide: it consumes the alkalis in the matrix and limits the geopolymer formation [26]. On the other hand, when incorporated with fly ash, iron oxides may fill large pore volumes of the ash, leading to a reduction in water demand and an increased compressive strength [29]. Finally, it increases 
the stability of the material against sulphate attack, which is known to deteriorate the concrete properties [26].

The reactivity of a fly ash is closely related to its unburnt material content [31]. High specific surface areas of non-reactive porous and rough particles, such as unburnt carbon, are responsible for increasing the water demand of a workable mixture. As a result of increasing the amount of water added, the alkalinity of the solution decreases, which might lead to increased reaction times for geopolymerisation, or decreased compressive strength of the final material in the case of insufficient alkali concentrations [38]. Finally, high unburnt carbon (>10 wt.\%) is responsible for changing the characteristic colour of the geopolymer composite darker and increasing the concentrations of water-soluble chlorides, which is known to increase corrosion [39]. Therefore, the EU limits [40] the highest content of loss on ignition in fly ash to 5-9\% for its applications in concrete. High loss on ignition obtained in the case of FA3 and GLD exceed the maximum LOI allowed and hamper their application as raw materials.

\subsection{Mineral Compositions}

The XRD patterns of the samples are shown in Figure 3. Both FA1 (Figure 3a) and FA2 (Figure $3 b)$ contain anhydrite $\left(\mathrm{CaSO}_{4}\right)$, gehlenite $\left(\mathrm{Ca}_{2} \mathrm{Al}_{2} \mathrm{SiO}_{7}\right)$, lime $(\mathrm{CaO})$ and quartz $\left(\mathrm{SiO}_{2}\right)$. In addition, FA1 contains portlandite $\left(\mathrm{Ca}(\mathrm{OH})_{2}\right)$, whereas it is replaced with calcite $\left(\mathrm{Ca}(\mathrm{CO})_{3}\right)$ in FA2. These findings are consistent with those of other studies $[18,41,42]$. According to Figure $3 c$, FA3 contains mullite $\left(\mathrm{Al}_{6} \mathrm{Si}_{2} \mathrm{O}_{13}\right)$ and quartz $\left(\mathrm{SiO}_{2}\right)$, whose presence has been reported previously [17]. As can be seen in Figure 3d, the biomass bottom ash consists of quartz $\left(\mathrm{SiO}_{2}\right)$ and albite $\left(\mathrm{NaAlSi}_{3} \mathrm{O}_{8}\right)$ while the main crystalline phase detected in dregs (Figure 3e) was calcite, which agrees with the previous investigations [5,40] and the high content of $\mathrm{CaCO}_{3}$ observed in the XRF analysis (Table 6). Limestone tailings show a slightly different crystalline structure: MTF (Figure 3f) contain calcite, dolomite, wollastonite, while quartz, diopside $\left(\mathrm{MgCaSi}_{2} \mathrm{O}_{6}\right)$ and wollastonite $\left(\mathrm{CaSiO}_{3}\right)$ were observed in MT which reflects the other studies [43]. Steel slag (Figure 3h) contains larnite $(\beta-$ $\left.\mathrm{Ca}_{2} \mathrm{SiO}_{4}\right)$, wustite $(\mathrm{FeO})$ and srebrodolskite $\left(\mathrm{Ca}_{2} \mathrm{FeAlO}_{5}\right)$. The presence of larnite and wustite in EAFSS was previously noted by other studies [27,29].

The narrow and sharp peaks of BA, MT, MTF and GLD (Figure 3) suggest a more crystalline structure compared to the other samples. On the other hand, the broad and wide halos between $20^{\circ}$ and $40^{\circ}(2 \theta)$ for FA3 (Figure $3 \mathrm{c}$ ), and $10^{\circ}$ and $30^{\circ}(2 \theta)$ for SS (Figure $3 \mathrm{~h}$ ) indicate a large amorphous content [11]. According to Figure 3, the order of the crystallinity was $\mathrm{BA}>\mathrm{GLD}>\mathrm{MT}>\mathrm{FA} 3>\mathrm{FA} 1>\mathrm{FA} 2>\mathrm{SS}$. The crystalline and amorphous contents of aluminosilicate sources play a significant role in the production of geopolymer composites. The crystalline phase in coal fly ash consists of quartz and mullite primarily, and quartz is only partially involved in the geopolymerisation reactions, which result in the production of composites with low mechanical strength. The vitreous phase, on the contrary, is easily dissolved in the alkaline solution, and therefore the rate of geopolymerisation reaction is proportional to the vitreous content $[19,31]$. According to the correlation between the amorphous content and the mechanical properties of a geopolymer composite, the high level of crystallinity observed in BA, GLD, MTF and MT might indicate that these streams are not well suitable as binders for geopolymer composites. 

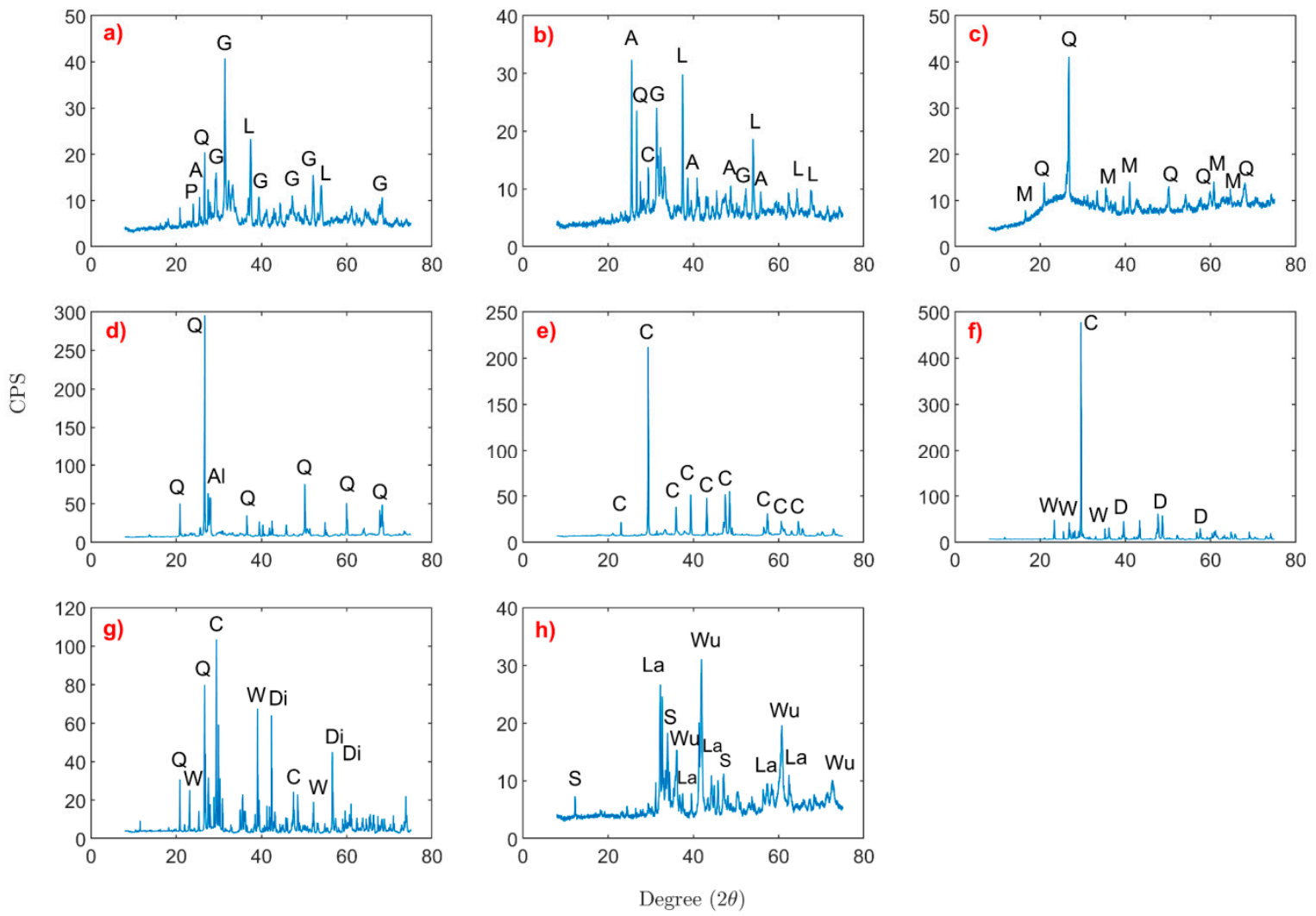

Figure 3. XRD patterns of the samples, a: biomass fly ash (FA1) 1, b: biomass fly ash 2 (FA2), c: coal fly ash (FA3), d: bottom ash (BA), e: green liquor dregs (GLD), f: fine limestone tailings (MTF), g: coarse limestone tailings (MT), h: steel slag (SS); Captions: A: anhydrite, Al: albite, C: calcite, D: dolomite, Di: diopside, G: gehlenite, L: lime, La: larnite, M: mullite, P: portlandite, Q: quartz, S: srebrodolskite (aluminian), W: wollastonite, Wu: wustite.

\subsection{Hazardous Elements' Concentrations and Leaching Tests}

The ICP-MS analysis was performed after complete dissolution of the solid samples, and the concentrations of potentially hazardous elements in the industrial side streams are presented in Table 7. When a comparison is made between FA2 and BA that originates from the same boiler, the concentrations of all the hazardous metals are higher in the fly ash than the bottom ash, which agrees with the literature [40]. High $\mathrm{Cr}(7690 \mathrm{mg} / \mathrm{kg})$ concentrations in electric arc furnace steel slag were also found in other studies [44]. When all samples are compared with respect to their hazardous elements content, limestone tailings contain the lowest concentrations within the sample group. The limit values for harmful elements content in fly and bottom ashes in the Government Decree concerning the Recovery of Certain Wastes in Earth Construction (Decree 591/2006) issued by the Finnish Ministry of the Environment are given in Table 7 [45]. With respect to these values, FA2 exceeds the limits for $\mathrm{Cu}, \mathrm{Zn}$ and $\mathrm{Pb}$, the concentrations of $\mathrm{Cu}$ and $\mathrm{Zn}$ exceed given limits in BA, SS exceeds the limit for $\mathrm{Cr}$, while $\mathrm{Zn}$ concentration exceeds the limit value in case of GLD. 
Table 7. Concentrations of hazardous elements in samples (after the complete dissolution of the solids), quantification limits (LOQ) and limit values for the content of harmful metals in fly and bottom ashes generated from coal, peat and wood according to the Finnish Government Decree 591/2006, values expressed in $\mathrm{mg} \mathrm{kg}^{-1}$ dry matter [45].

\begin{tabular}{cccccccc}
\hline & $\mathbf{C r}$ & $\mathbf{N i}$ & $\mathbf{C u}$ & $\mathbf{Z n}$ & $\mathbf{A s}$ & $\mathbf{C d}$ & $\mathbf{P b}$ \\
\hline LOQ & 2 & 2 & 2 & 2 & 10 & 2 & 10 \\
Limit & 400 & - & 400 & 2000 & 50 & 15 & 300 \\
FA1 & 58 & 24 & 76 & 1720 & $<10$ & 6.2 & 20 \\
FA2 & 199 & 112 & 1910 & 3630 & 34 & 11 & 770 \\
FA3 & 71 & 84 & 65 & 106 & 21 & $<2$ & 30 \\
BA & 111 & 56 & 1970 & 2690 & 25 & $<2$ & 165 \\
GLD & 193 & 75 & 338 & 3342 & $<10$ & 27 & 25 \\
MTF & 23 & 7 & 14 & 73 & $<10$ & $<2$ & $<10$ \\
MT & 24 & 11 & 9 & 76 & $<10$ & $<2$ & $<10$ \\
SS & 7690 & 52 & 129 & 275 & $<10$ & $<2$ & $<10$ \\
\hline
\end{tabular}

The Government Decree concerning the Recovery of Certain Wastes in Earth Construction (Decree 843/2017) also sets limits for the solubility of these elements, as their leaching could hinder the application of secondary raw materials in earth construction [46]. These limits and the leaching results (EN-12457-2, shaking for $24 \mathrm{~h}, \mathrm{~L} / \mathrm{S}=10$ ) for each industrial residue are presented in Table 8 [47]. As can be seen in Table 8, no element exceeds the maximum allowable leaching limit, indicating that with respect to the leachable hazardous element contents, these samples could be suitable for the production of geopolymer composites.

Table 8. Concentrations of different hazardous elements in samples after leaching, quantification limits (LOQ) and limit values for solubility of harmful substances (mg/kg, L/S = 10 L/ kg) in fly ashes and bottom ashes generated from coal, peat, and wood according to the Finnish Government Decree 843/2017 [46], n.d.: not determined.

\begin{tabular}{cccccccc}
\hline & $\mathbf{C r}$ & $\mathbf{N i}$ & $\mathbf{C u}$ & $\mathbf{Z n}$ & $\mathbf{A s}$ & $\mathbf{C d}$ & $\mathbf{P b}$ \\
\hline LOQ & 0.004 & 0.006 & 0.003 & 0.04 & 0.004 & 0.001 & 0.002 \\
Limit & 10 & 2 & 10 & 15 & 2 & 0.06 & 2 \\
FA1 & 0.103 & n.d. & n.d. & 0.41 & n.d. & n.d. & n.d. \\
FA2 & 3.01 & n.d. & n.d. & 1.06 & $<0.004$ & n.d. & 0.01 \\
FA3 & 1.31 & 0.007 & 0.07 & n.d & 0.007 & 0.005 & 0.002 \\
BA & 5.56 & n.d. & n.d. & 2.03 & 0.006 & n.d. & 0.05 \\
GLD & 3.46 & n.d. & n.d. & 1.2 & 0.005 & n.d. & 0.03 \\
MTF & 1.29 & n.d. & n.d. & n.d. & 0.006 & n.d. & n.d. \\
MT & 1.32 & n.d. & n.d. & n.d. & 0.007 & n.d. & n.d. \\
SS & 0.86 & 0.09 & 0.08 & n.d. & 0.008 & 0.005 & 0.002 \\
\hline
\end{tabular}

\subsection{Thermogravimetric Analysis}

Thermogravimetry (TG) and the normalised MS curves for $\mathrm{H}_{2} \mathrm{O}$ and $\mathrm{CO}_{2}$ released from the samples are presented in Figures 4 and 5, respectively. The first slight weight loss, corresponding to temperatures below $200^{\circ} \mathrm{C}$ in Figure 4, may be attributed to the release of surface water from the particles, which can also be seen as a weight increase in the $\mathrm{m} / \mathrm{z}$ 18 line in Figure 5a [21]. According to Figure 5a, it can be said that only GLD contains a small amount of adsorbed water at its surface, as no peak was observed in the $\mathrm{m} / \mathrm{z} 18$ line for the other samples. 


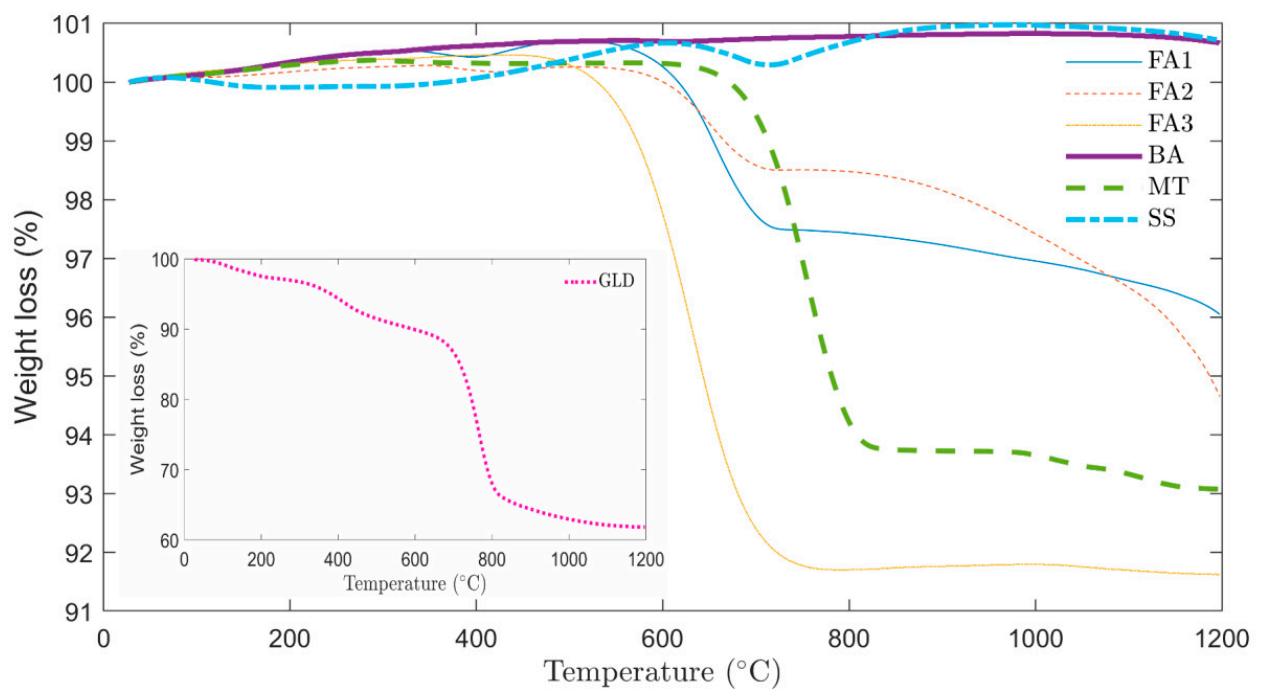

Figure 4. TG curves of the samples: FA1 (biomass fly ash 1), FA2 (biomass fly ash 2), FA3 (coal fly ash), BA (biomass bottom ash), GLD (green liquor dregs), MT (coarse limestone tailings) and SS (steel slag).
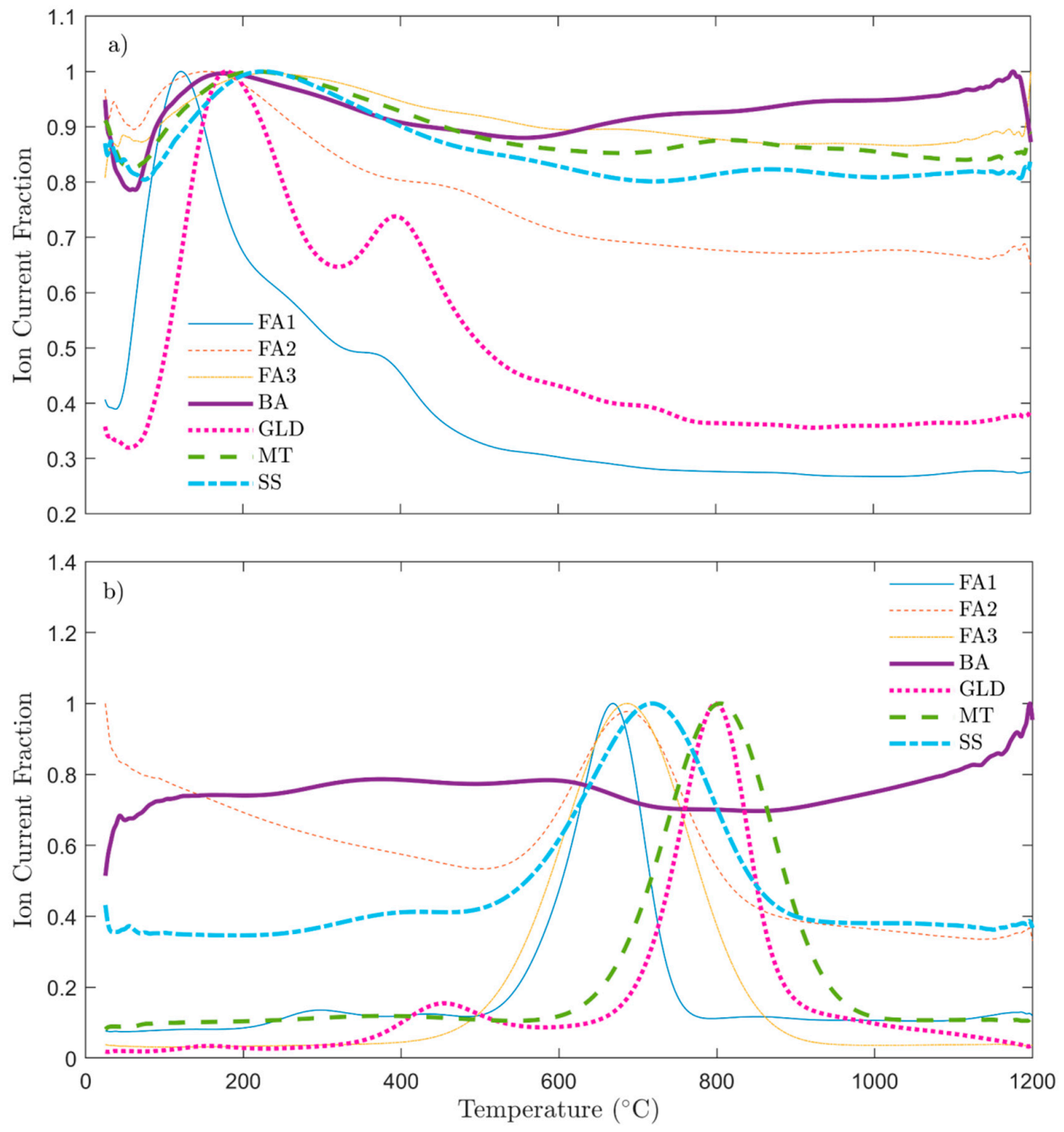

Figure 5. Normalised MS curves of the samples: (a) $m / z=18$ line $\left(\mathrm{H}_{2} \mathrm{O}\right),(\mathbf{b}) \mathrm{m} / \mathrm{z}=44$ line $\left(\mathrm{CO}_{2}\right)$, FA1 (biomass fly ash 1$)$, FA2 (biomass fly ash 2), FA3 (coal fly ash), BA (bottom ash), GLD (green liquor dregs), MT (coarse limestone tailings) and SS (steel slag). 
The weight losses between 400 and $700{ }^{\circ} \mathrm{C}$ are attributed to the oxidation of the unburnt material content. These reactions can also be observed in the increase of the ion current representing the release of $\mathrm{CO}_{2}(\mathrm{~m} / \mathrm{z}=44)$ in Figure $5 \mathrm{~b}$. In the case of FA1, the weight loss could also be due to the dehydration of $\mathrm{Ca}(\mathrm{OH})_{2}$, whose presence was shown in Figure 3 above. The increase in $\mathrm{m} / \mathrm{z} 18$ line supports the dehydration of the hydrated lime for this sample $[35,36,48]$. No weight loss was observed within this temperature range in the case of bottom ash, limestone tailings, and steel slag, suggesting that these side streams do not contain unburnt carbon. The weight losses observed among the samples were as following: GLD > FA3 > FA1 > FA2. In the case of GLD, the weight loss of $9 \%$ is attributed to the unburnt carbon and the organic matter [21]. The weight loss in FA3 (8\%) is due to its high unburnt carbon content [35].

The weight losses occurring after $700{ }^{\circ} \mathrm{C}$ are likely to be related to the $\mathrm{CaCO}_{3}$ decomposition reactions which produce $\mathrm{CaO}$ and $\mathrm{CO}_{2}[21,36,48,49]$. With respect to their weight loss in this range, the samples can be ordered as following GLD > MT > FA2 > FA1 > SS The extraordinarily high weight loss of GLD and MT may be attributed to the high $\mathrm{CaCO}_{3}$ contents, which agrees with the presence of calcite (Figure 3). BA shows no weight loss, suggesting very low contents of $\mathrm{CaCO}_{3}$.

The weight losses of the samples during the entire thermogravimetric analysis were $4 \%$ (FA1), 5.5\% (FA2), 8.5\% (FA3), 38\% (GLD) and 7.5\% (MT). These values are consistent with the LOI values presented in Table 5. With respect to the standard specifications and previous studies, prior to their incorporation in geopolymer composites as binders, the unburnt carbon contents in the FA3 and GLD must be reduced.

\subsection{Characteristics of the Prepared Geopolymer Composites}

The side stream selection to produce geopolymer composites was determined according to the analysis performed. FA1 was applied as the binder due to its smaller amount of toxic metals compared to the ones present in FA2 and SS. GLD was not applied as filler since they contain a considerable amount of organics and unburnt material. The compressive and flexural strengths of the prepared composites are presented in Figure 6, while the initial setting times and abrasion resistance results are shown in Table 9. Metakaolin-based geopolymer composite (GP1) developed 25.1 MPa of compressive strength and 8.1 MPa flexural strength, whereas they were measured as 50.0 and $6.0 \mathrm{MPa}$ in the case of reference composite after 28 days. The compressive strength of GP2 was measured as $2.3 \mathrm{MPa}$ after 7 days. Despite its significant increase to $14.1 \mathrm{MPa}$ (by 513\%) after 28 days, this value is below the minimum requirement for a structural construction material. The drastic increase in the compressive strength of GP2 between 7 and 28 days suggests that the most significant geopolymerisation reactions occur after 7 days, which is different from the strength development of the reference product and GP1, which produce over $80 \%$ of the maximum compressive strength in the first 7 days. This retardation may be attributed due to the slower kinetics of aluminosilicates dissolution and polycondensation reactions [18]. The relatively low compressive strength of GP2 may be attributed to the high concentration of calcium in FA1, which is known to reduce the compressive strength of the material by shortening the setting time of the fresh paste so much that the sequential geopolymerisation reactions do not occur appropriately [18]. Even though the maximum compressive strength reached in this study $(14.1 \mathrm{MPa})$ is lower than that obtained in previous studies, see e.g., $[6,19,22]$, the purpose of this work was to prove the applicability of more challenging industrial side streams (biomass fly ash and limestone tailings) with no pre-treatment, rather than aiming at achieving the best mechanical properties. Further improvements can be obtained by reduction of the calcium and iron content, particle size reduction, or by increasing the temperature, and the solution alkalinity. Nevertheless, GP2 can find applications in paving flags (EN 1339) and in concrete kerb units (EN 1340). 


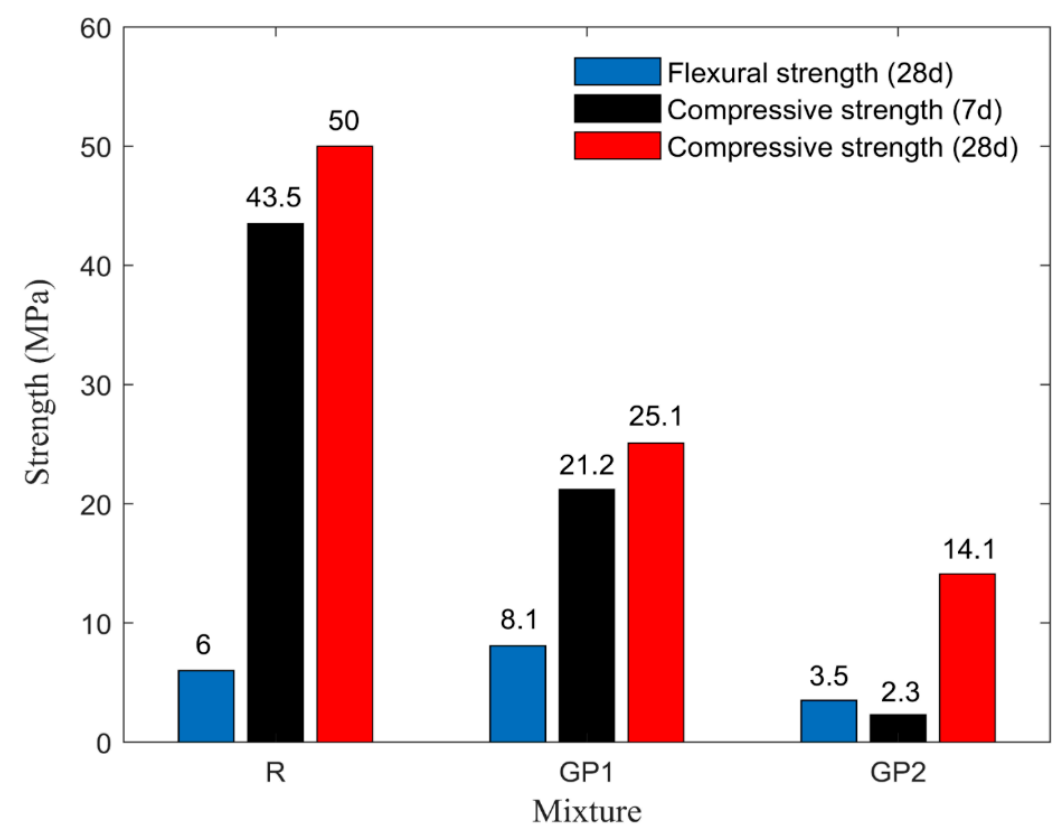

Figure 6. The flexural and compressive strength test results of the produced composites.

Table 9. Characteristics of the prepared composites: R: reference concrete, GP1: metakaolin-based geopolymer composite and GP2: stream-based geopolymer composite.

\begin{tabular}{cccc}
\hline & R & GP1 & GP2 \\
\hline Initial setting time (min) & 120 & 90 & 110 \\
Abrasion resistance (mm) & 23 & 24 & N/A \\
7 days compressive strength (MPa) & 43.5 & 21.2 & 2.3 \\
28 days compressive strength (MPa) & 50.0 & 25.1 & $14.1^{*}$ \\
Flexural Strength (MPa) & 6.0 & 8.1 & 3.5 \\
\hline
\end{tabular}

* $40 \times 40 \times 40 \mathrm{~mm}^{3}$ cube.

\section{Conclusions}

In this work, side streams obtained from the forest, pulp, energy and mining industries were investigated to assess their suitability without any pre-treatment as raw materials for geopolymer composites in the construction industry. The combination of the findings provides support for the conceptual premise that FA1 and FA3 are the most suitable side streams to produce geopolymer composites due to their high amorphous content, small toxic metal concentrations, large content of $\mathrm{Al}$ and $\mathrm{Si}$ and high specific surface area with correspondingly small particle sizes. FA1 was chosen over FA3 since it contains a significantly smaller loss on ignition value. Bottom ash is not suitable as a binder or coarse filler without milling due to its small aluminium concentration, very coarse particles and high concentrations of toxic metals. Fine and coarse limestone tailings can be used as aggregates due to their thermal stability, smaller toxic metals concentration and acceptable particle size distributions. The results of the mechanical properties tests show that the reference composite $(\mathrm{R})$ has the highest compressive (50 MPa) and flexural strength (6.0 MPa). The metakaolin-based geopolymer composite (GP1) exhibits sufficient compressive and flexural strength for its application in structural construction, while GP2 can be utilised in concrete kerb units and paving flags with a 14.1 and $3.3 \mathrm{MPa}$ compressive and flexural strength, respectively. These findings provide a deeper insight into the use of secondary raw materials in geopolymer composites as binders and fine and coarse aggregates. Nevertheless, more experimental studies are required on the production of geopolymer composites to improve the characteristics of the final product. 
Supplementary Materials: The following are available online at https:/ / www.mdpi.com/article/10 $.3390 / \min 11060593 / \mathrm{s} 1$, Figure S1. EDS mappings of the samples showing Al and Si content: A: FA1, B: FA2, C: FA3, D: BA, E: GLD, F: MTF, G: MT and H: SS.

Author Contributions: Conceptualization, M.E.K.; methodology, M.E.K.; software, M.E.K. and J.T.; validation, M.E.K., T.K. and A.H.; Formal analysis, M.E.K., O.M. and J.T.; Investigation, M.E.K.; Resources, J.T., O.M. and A.H.; Data curation, M.E.K., O.M. and J.T.; Writing—original draft preparation, M.E.K., J.T.; Writing—review and editing, M.E.K.; Visualization, M.E.K.; Supervision, T.K. and A.H.; Project administration, A.H.; Funding acquisition, A.H. All authors have read and agreed to the published version of the manuscript.

Funding: This research was funded by European Regional Development Fund, grant number UIA02-155.

Data Availability Statement: Not applicable.

Acknowledgments: This work was supported financially by the European Regional Development Fund through the Urban Innovative Actions Initiative (grant number UIA02-155).

Conflicts of Interest: The authors declare no conflict of interest.

\section{References}

1. European Commission. 2030 Climate \& Energy Framework. 2014. Available online: https://ec.europa.eu/clima/policies/ strategies /2030_en\#tab-0-0 (accessed on 17 October 2019).

2. Andrew, R.M. Global CO2 emissions from cement production. Earth Syst. Sci. Data 2018, 10, 2213-2239. [CrossRef]

3. Rajamma, R.; Ball, R.J.; Tarelho, L.A.; Allen, G.C.; Labrincha, J.A.; Ferreira, V.M. Characterisation and use of biomass fly ash in cement-based materials. J. Hazard. Mater. 2009, 172, 1049-1060. [CrossRef]

4. Mucsi, G.; Kumar, S.; Csőke, B.; Kumar, R.; Molnár, Z.; Rácz, Á.; Mádai, F.; Debreczeni, Á. Control of geopolymer properties by grinding of land filled fly ash. Int. J. Miner. Process. 2015, 143, 50-58. [CrossRef]

5. Novais, R.M.; Carvalheiras, J.; Senff, L.; Labrincha, J.A. Upcycling unexplored dregs and biomass fly ash from the paper and pulp industry in the production of eco-friendly geopolymer mortars: A preliminary assessment. Constr. Build. Mater. 2018, 184, 464-472. [CrossRef]

6. Askarian, M.; Tao, Z.; Samali, B.; Adam, G.; Shuaibu, R. Mix composition and characterisation of one-part geopolymers with different activators. Constr. Build. Mater. 2019, 225, 526-537. [CrossRef]

7. Davidovits, J. Geopolymer Chemistry and Applications, 4th ed; Geopolymer Institute: Saint-Quentin, France, 2011.

8. Chindaprasirt, P.; Jaturapitakkul, C.; Sinsiri, T. Effect of fly ash fineness on microstructure of blended cement paste. Constr. Build. Mater. 2007, 21, 1534-1541. [CrossRef]

9. Defáveri, K.D.C.E.S.; dos Santos, L.F.; de Carvalho, J.M.F.; Peixoto, R.A.F.; Brigolini, G.J. Iron ore tailing-based geopolymer containing glass wool residue: A study of mechanical and microstructural properties. Constr. Build. Mater. 2019, $220,375-385$. [CrossRef]

10. Samantasinghar, S.; Singh, S.P. Effect of synthesis parameters on compressive strength of fly ash-slag blended geopolymer. Constr. Build. Mater. 2018, 170, 225-234. [CrossRef]

11. Guo, X.; Shi, H.; Dick, W.A. Compressive strength and microstructural characteristics of class C fly ash geopolymer. Cem. Concr. Compos. 2010, 32, 142-147. [CrossRef]

12. Kumar, S.; Kristály, F.; Mucsi, G. Geopolymerisation behaviour of size fractioned fly ash. Adv. Powder Technol. 2015, 26, 24-30. [CrossRef]

13. Li, L.G.; Chen, J.-J.; Kwan, A.K. Roles of packing density and water film thickness in strength and durability of limestone fines concrete. Mag. Concr. Res. 2017, 12, 595-605. [CrossRef]

14. Kwan, A.; Mora, C.F. Effects of various shape parameters on packing of aggregate particles. Mag. Concr. Res. 2001, 2, 91-100. [CrossRef]

15. Izquierdo, M.; Querol, X. Leaching behaviour of elements from coal combustion fly ash: An overview. Int. J. Coal Geol. 2012, 94, 54-66. [CrossRef]

16. Vassilev, S.V.; Baxter, D.; Andersen, L.K.; Vassileva, C.G. An overview of the composition and application of biomass ash: Part 2. Potential utilisation, technological and ecological advantages, and challenges. Fuel 2013, 105, 19-39. [CrossRef]

17. Kaja, A.M.; Lazaro, A.; Yu, Q.L. Effects of Portland cement on activation mechanism of class F fly ash geopolymer cured under ambient conditions. Constr. Build. Mater. 2018, 189, 1113-1123. [CrossRef]

18. Abdulkareem, O.A.; Ramli, M.; Matthews, J.C. Production of geopolymer mortar system containing high calcium bio-mass wood ash as a partial substitution to fly ash: An early age evaluation. Compos. Part B Eng. 2019, 174, 106941. [CrossRef]

19. Lau, C.K.; Rowles, M.R.; Parnham, G.N.; Htut, T.; Ng, T.S. Investigation of geopolymers containing fly ash and ground-granulated blast-furnace slag blended by amorphous ratios. Constr. Build. Mater. 2019, 222, 731-737. [CrossRef]

20. Kinnarinen, T.; Golmaei, M.; Jernström, E.; Häkkinen, A. Separation, treatment and utilization of inorganic residues of chemical pulp mills. J. Clean. Prod. 2016, 133, 953-964. [CrossRef] 
21. Dos Santos, V.R.; Cabrelon, M.D.; de Sousa Trichês, E.; Quinteiro, E. Green liquor dregs and slaker grits residues char-acterization of a pulp and paper mill for future application on ceramic products. J. Clean. Prod. 2019, 240, 118220. [CrossRef]

22. Martínez-Lage, I.; Velay-Lizancos, M.; Vázquez-Burgo, P.; Rivas-Fernández, M.; Vázquez-Herrero, C.; Ramírez-Rodríguez, A.; Martín-Cano, M. Concretes and mortars with waste paper industry: Biomass ash and dregs. J. Environ. Manag. 2016, 181, 863-873. [CrossRef]

23. Jones, H.; Boger, D.V. Sustainability and Waste Management in the Resource Industries. Ind. Eng. Chem. Res. 2012, 51, 10057-10065. [CrossRef]

24. Manjarrez, L.; Zhang, L. Utilization of Copper Mine Tailings as Road Base Construction Material through geopoly-merization. J. Mater. Civ. Eng. 2018, 30, 04018201. [CrossRef]

25. Grubeša, I.N.; Barišić, I.; Fucic, A.; Bansode, S.S. Characteristics and Uses of Steel Slag in Building Construction; Woodhead Publishing: Sawston, UK; Elsevier: Amsterdam, The Netherlands, 2016; pp. 67-68.

26. Khater, H.M. Hybrid slag geopolymer composites with durable characteristics activated by cement kiln dust. Constr. Build. Mater. 2019, 228, 116708. [CrossRef]

27. Santamaria, A.; Faleschini, F.; Giacomello, G.; Brunelli, K.; San José, J.-T.; Pellegrino, C.; Pasetto, M. Dimensional stability of electric arc furnace slag in civil engineering applications. J. Clean. Prod. 2018, 205, 599-609. [CrossRef]

28. Roslan, N.H.; Ismail, M.; Abdul-Majid, Z.; Ghoreishiamiri, S.; Muhammad, B. Performance of steel slag and steel sludge in concrete. Constr. Build. Mater. 2016, 104, 16-24. [CrossRef]

29. Niklioć, I.; Marković, S.; Janković-Častvan, I.; Radmilović, V.V.; Karanović, L.; Babić, B.; Radmilović, V.R. Modi-fication of mechanical and thermal properties of fly ash-based geopolymer by the incorporation of steel slag. Mater. Lett. 2016, 176, 301-305. [CrossRef]

30. Zhu, Z.; Wang, X.; Dai, S.; Huang, B.; He, Q. Fractional Characteristics of Coal Fly Ash for Beneficial Use. J. Mater. Civ. Eng. 2013, 25, 63-69. [CrossRef]

31. Fernández-Jiménez, A.; Palomo, A. Characterisation of fly ashes. Potential reactivity as alkaline cements. Fuel 2003, 18, 2259-2265. [CrossRef]

32. Hafid, H.; Ovarlez, G.; Toussaint, F.; Jezequel, P.H.; Roussel, N. Effect of particle morphological parameters on sand grains packing properties and rheology of model mortars. Cem. Concr. Res. 2016, 80, 44-51. [CrossRef]

33. Cho, G.-C.; Dodds, J.; Santamarina, J.C. Particle Shape Effects on Packing Density, Stiffness, and Strength: Natural and Crushed Sands. J. Geotech. Geoenviron. Eng. 2006, 132, 591-602. [CrossRef]

34. Mora, C.; Kwan, A. Sphericity, shape factor, and convexity measurement of coarse aggregate for concrete using digital image processing. Cem. Concr. Res. 2000, 30, 351-358. [CrossRef]

35. Haq, E.U.; Padmanabhan, S.K.; Licciulli, A.A. Synthesis and characteristics of fly ash and bottom ash based geopolymers-A comparative study. Ceram. Int. 2014, 40, 2965-2971. [CrossRef]

36. Magdziarz, A.; Gajek, M.; Nowak-Woźny, D.; Wilk, M. Mineral phase transformation of biomass ashes-Experimental and thermochemical calculations. Renew. Energy 2018, 128, 446-459. [CrossRef]

37. Chindaprasirt, P.; De Silva, P.; Sagoe-Crentsil, K.; Hanjitsuwan, S. Effect of $\mathrm{SiO} 2$ and $\mathrm{Al} 2 \mathrm{O} 3$ on the setting and hardening of high calcium fly ash-based geopolymer systems. J. Mater. Sci. 2012, 47, 4876-4883. [CrossRef]

38. Hajimohammadi, A.; van Deventer, J.S. Solid reactant-based geopolymers from rice hull ash and sodium aluminate. Waste Biomass Valori. 2016, 6, 2131-2140. [CrossRef]

39. Ha, T.-H.; Muralidharan, S.; Bae, J.-H.; Ha, Y.-C.; Lee, H.-G.; Park, K.W.; Kim, D.-K. Effect of unburnt carbon on the corrosion performance of fly ash cement mortar. Constr. Build. Mater. 2005, 19, 509-515. [CrossRef]

40. EN 450-1-Fly Ash for Concrete. Part 1: Definition, Specifications and Conformity Criteria. Available online: https://sales.sfs.fi/ fi/index/tuotteet/SFS/CEN/ID2/4/203748.html.stx (accessed on 2 December 2020).

41. Dahl, O.; Nurmesniemi, H.; Pöykiö, R.; Watkins, G. Heavy metal concentrations in bottom ash and fly ash fractions from a large-sized (246MW) fluidized bed boiler with respect to their Finnish forest fertilizer limit values. Fuel Process. Technol. 2010, 91, 1634-1639. [CrossRef]

42. Lin, W.Y.; Prabhakar, A.K.; Mohan, B.C.; Wang, C.-H. A factorial experimental analysis of using wood fly ash as an alkaline activator along with coal fly ash for production of geopolymer-cementitious hybrids. Sci. Total. Environ. 2020, $718,135289$. [CrossRef]

43. Solismaa, S.; Ismailov, A.; Karhu, M.; Sreenivasan, H.; Lehtonen, M.; Kinnunen, P.; Illikainen, M.; Räisänen, M. Valorization of Finnish mining tailings for use in the ceramics industry. Bull. Geol. Soc. Finl. 2018, 90, 33-54. [CrossRef]

44. Tossavainen, M.; Engstrom, F.; Yang, Q.; Menad, N.; Lidstrom Larsson, M.; Bjorkman, B. Characteristics of steel slag under different cooling conditions. Waste Manag. 2007, 27, 1335-1344. [CrossRef] [PubMed]

45. Finnish Ministry of the Environment. Valtioneuvoston Asetus Eräiden Jätteiden Hyödyntämisestä Maarakentamisessa 591/2006. 2010. (In Finnish). Available online: https:/ / www.finlex.fi/fi/laki/alkup/2006/20060591 (accessed on 26 March 2020).

46. Finnish Ministry of the Environment. Valtioneuvoston Asetus Eräiden Jätteiden Hyödyntämisestä Maarakentamisessa 843/2017. 2017. (In Finnish). Available online: https:/ / www.finlex.fi/fi/laki/alkup/2017/20170843 (accessed on 26 March 2020). 
47. EN 12457-2 - Characterisation of Waste-Leaching-Compliance Test for Leaching of Granular Waste Materials and SludgesPart 2: One Stage Batch Test at a Liquid to Solid Ratio of $10 \mathrm{~L} / \mathrm{kg}$ for Materials with Particle Size below $4 \mathrm{Mm}$ (Without or with Size Reduction). Available online: https://sales.sfs.fi/en/index/tuotteet/SFS/CEN/ID2/1/4717.html.stx (accessed on 2 December 2020).

48. Tarelho, L.; Teixeira, E.; Silva, D.; Modolo, R.; Labrincha, J.; Rocha, F. Characteristics of distinct ash flows in a biomass thermal power plant with bubbling fluidised bed combustor. Energy 2015, 90, 387-402. [CrossRef]

49. Masindi, V.; Madzivire, G.; Tekere, M. Reclamation of water and the synthesis of gypsum and limestone from acid mine drainage treatment process using a combination of pre-treated magnesite nanosheets, lime, and CO2 bubbling. Water Resour. Ind. 2018, 20, 1-14. [CrossRef] 